\title{
"A peaceful country": Refugees, masculinities and anti-radical national identity in early postcolonial Botswana
}

\author{
Phuthego Phuthego Molosiwa and Maitseo M.M. Bolaane*
}

\begin{abstract}
Here, we tell the story of early postcolonial Botswana's struggles to refine its citizenship model in the midst of a hostile political environment between the 1960s and 1980s. While being one of the "most peaceful" countries in the region at the time, and in order to stem the tide of militant immigrants, the majority of whom were men, Botswana opted to narrow its citizenship model. Many refugees and exiles were denied citizenship because their "radical masculinities" appeared to present a threat to the existing peace in the country. The article deals with the important question of how Botswana's historically rooted, patriarchal gender regime influenced the country's refashioning of its citizenship model against the backdrop of the influx of exiles and refugees of wars of independence. We draw largely from existing scholarship on Botswana's role in the liberation struggle. In addition, the extant refugees archive, letters to the editor of the Kutlwano magazine, Seretse Khama's speeches and the Botswana Citizenship Act of 1982/1984 provide primary accounts of how the government and the public attempted to develop and achieve a peaceful, anti-radical national identity during this tumultuous period.
\end{abstract}

Keywords: Botswana; citizenship; masculinities; refugees; liberation struggle.

\section{Opsomming}

Hier vertel ons die verhaal van post-koloniale Botswana se vroeë jare, en bepaal die uitdagings wat betref sy burgerskapmodel te midde van die vyandige politieke klimaat wat die 1960's tot 1980's gekenmerk het. Alhoewel Botswana in dié tyd een van die mees "vreedsame" lande in die streek was, het hy te kampe gehad met 'n vloedgolf

* Phuthego Phuthego Molosiwa is senior lecturer at the Botswana Open University and is head of Environmental Studies in the School of Social Sciences. He is also a research fellow of the History Department at the University of Free State. He recently coauthored a chapter on the history of Lake Ngami and its ecosystems and has published widely on the topics of vulnerability and community resilience, and on the histories of disease and ethnicity in Botswana. Maitseo M.M. Bolaane is an associate professor (Department of History) at the University of Botswana and director of the San Research Centre. She is active in the University of Botswana/University of Troms $\varnothing$ Collaborative Programme for San Research and Capacity Building. She has recently co-edited two books: Under the Same Sun: San and Sami Peoples and Research, and Botswana Women Write. 
militante immigrante, waarvan die meerderheid mans was. Botswana het daarom gekies om sy burgerskapmodel te vernou. Vele vlugtelinge en uitgewekenes is burgerskap geweier omdat hulle "radikale manlikheid" as 'n bedreiging vir die heersende vrede in die land beskou is. Hierdie artikel stel belangrike vrae oor Botswana se histories-gewortelde patriargale geslags regime, en die invloed daarvan op die land se hervorming van sy burgerskapmodel, aan die hand van die instroming van uitgewekenes en vlugtelinge van vryheidsoorloë. Ons beroep ons op gevestigde navorsing oor Botswana se rol in die vryheidstryd. Verder verskaf die bestaande vlugtelinge-argief, briewe aan die redakteur van die Kutlwano tydskrif, Seretse Khama se toesprake en die Botswana Burgerskap Wet van 1982/1984, primêre verslae oor die regering en die publiek se pogings om 'n vreedsame, anti-radikale nasionale identiteit tydens dié ontstuimige tydperk te ontwikkel.

Sleutelwoorde: Botswana; burgerskap; manlikheid; vlugtelinge; vryheidstryd.

\section{Introduction}

Botswana gained independence from British colonial rule in 1966. By 1970 this impoverished former colonial backwater found itself having to negotiate the threat to its peace and stability posed by the surrounding white settler minority regimes of Southern Rhodesia (present-day Zimbabwe), South West Africa (Namibia), and most especially by South Africa which bordered Botswana from east to west. At the time, Botswana was one of the frontline states, a coalition of independent countries, including Zambia and Tanzania, later joined by Angola, Mozambique and Zimbabwe. ${ }^{1}$ This coalition was committed to opposing the racially discriminatory policies of white minority regimes, especially the policy of apartheid in South Africa, and it did this primarily by providing a sanctuary to hundreds of thousands of refugees of the liberation struggle.

During this time, liberation wars were at their climax as Africans in the region were fighting to reclaim their independence from white minority rule. One of the few independent countries in the region at the time, and perhaps the most stable and peaceful politically, Botswana became a sanctuary for the tens of thousands of African refugees and exiles who fled political persecution in Southern Rhodesia, South West Africa, Angola, Mozambique and South Africa. ${ }^{2}$ Its foreign policy of non-alignment to any of the white-dominated states surrounding it, and its relatively peaceful political

1. M. Evans, "The Frontline-States, South Africa and Southern African Security: Military Prospects and Perspectives", Zambezia, 12, 1984/5, pp 1-19; G. Arnold, The A to Z of the Non-Aligned Movement and Third World (Scarecrow Press, Plymouth, 2006), pp 126-127.

2. In 1980 the UNHCR estimated that by 1978 there were 20000 refugees and asylum seekers living in the only refugee camp in Botswana, the Dukwi Refugee Camp. See D. Ntseane and R. Mupedziswa, "Fifty Years of Democracy: Botswana's Experience in Caring for Refugees and Displaced Persons", International Journal of Development and Sustainability, 7, 4, 2018, p 1412. 
environment, untainted by experiences of radical liberation politics, made Botswana an attractive destination for political refugees and exiles. Botswana's inclination towards peace and its aversion to overt violence are reflected in the Tswana proverb, "Ntwa kgolo ke ya molomo", which is translated literally as "the big war is that of the mouth" (dialogue is the best tool for resolving conflicts). ${ }^{3}$ The post-colonial government reappropriated this proverb, and recalibrated it to "peaceful resolution of conflict" and along with seven other tenets, used it in its foreign policy statement adopted on 28 March 1970.4

The philosophy of peace and stability in Botswana was, however, not simply expressed in the principles of consultation, such as "peaceful resolution of conflict" and "peaceful coexistence". It was complicated by a cultural context in which a deeply rooted patriarchal structure dominated power relations, in the process muting expressions of gender by women, the poor and young men. This patriarchal control persisted until the 1990s when it was challenged by an emergent, strong women's rights movement at the forefront of which was 'Emang Basadi' (lit. women stand up [for your rights]), which was an organisation formed following the Beijing 1995 Fourth World Conference on Women. ${ }^{5}$

Despite playing a central role in the process of southern African liberation from colonial rule, Botswana has received very little attention in the historiography of the liberation movement in Africa. This is primarily because Botswana had not experienced direct settler colonialism on any notable scale, leading to the absence of a local radical liberation movement. In fact, transition from colonial rule to independence was an initiative that came more from the colonising power, the British, in concert with a few Tswana elites and the royalty, than from any local nationalist movement. ${ }^{6}$ In this article we propose that even recent efforts towards assessing the role that Botswana played in the region's liberation struggle are not comprehensive because, in the main, they regard the country merely as a conduit through which

3. R.O.B. Nhlekisana, "A Reflection on Setswana Proverbs in Botswana's National Psyche and Nationhood", Botswana Notes and Records, 48. A Special Issue on Humanities at UB and Botswana's 50 Years of Independence, 2016, pp 153-154.

4. M. Niemann, "Diamonds are a State's Best Friend: Botswana's Foreign Policy in Southern Africa", Africa Today, 40, 1, 1993, pp 27-47; See also Southern Africa Report, https://issafrica.s3.amazonaws.com/site/uploads/SAReport Issue4.pdf. Accessed 19 April 2021.

5. Through the leadership of Emang Basadi, the women's movement in Botswana grew significantly between the 1980s and 1990s, with heightened women's rights mobilisation central to questions of citizenship. Emang Basadi was credited with accomplishing many significant victories, including winning a landmark case commonly known as the Unity Dow Citizenship Case. For important insights on this period of heightened women's rights mobilisation, see G. Bauer, "Update on the Women's Movement in Botswana: Have Women Stopped Talking?", African Studies Review, 54, 2, 2011, pp 23 and 26-31.

6. C. Saunders, "Botswana and the Liberation of Southern Africa", Social Dynamics, 34, 1, 2008, pp 2-4. 
refugees from the liberation wars passed since the 1950s. Commendably, the existing historiography does provide evidence of instances where the country suffered when the hostile white-dominated regimes harassed it for providing a sanctuary to political dissidents. ${ }^{7}$ Indeed, the question of Botswana's vulnerability in a region dominated by oppressive minority regimes forms the grand narrative of the current state of knowledge. These scholars have focused primarily on South African and Rhodesian military incursions into Botswana between the 1970s and the first half of the 1990s. ${ }^{8}$ Such renditions have accorded foreign excursions priority but, we suggest, have obscured the internal and nuanced ways through which the country negotiated its responses to the aggression of white minority regimes. For instance, as part of its strategy to protect its population from such aggression, the Botswana government, at the helm of which was its pragmatic first president, Seretse Khama, was receptive to refugees but, it is important to note, it also made a conscious decision to deny citizenship in Botswana to refugees of the liberation struggle.

In addition, there was always a certain unease and discomfort at government level about what we term "radical masculinities" on the part of many of the refugees. Such anxieties were as much expressed in government policy as they were in public discourse. As a result, the refugees (and/or exiles), whether or not given asylum, were excluded from citizenship of the country because their "radical masculinities" were perceived as presenting a threat to the existing peace in the country. Moreover, to rid the country of these so-called "radical masculinities", Botswana embarked on an ambitious programme to redefine its citizenship model along peaceful, anti-radical masculine lines.

The hegemonic power of the patriarchy and its influence on citizenship in Botswana has historical salience and it antedates colonial rule. Studies of Tswana kingdoms present rigidly hierarchical structures dominated by male elites across precolonial and colonial temporal spaces. ${ }^{9}$ These deep roots of a powerful patriarchy ensured that men continued to exert hegemonic power, in the process defining the rights to citizenship of women well into post-colonial Botswana.

7. N. Parsons, "The Pipeline: Botswana's Reception of Refugees, 1956-1968", Social Dynamics, 34, 1, 2008, pp 17-32; P.T. Mgadla, “'A Good Measure of Sacrifice': Botswana and the Liberation Struggles in Southern Africa (1965-1985)", Social Dynamics, 34, 1, 2008, pp 33-53; W.G. Morapedi, "The Dilemmas of Liberation in Southern Africa: The Case of Zimbabwean Liberation Movements and Botswana, 1960-1979", Journal of Southern African Studies, 38, 1, 2012, pp 73-90; C.J. Makgala and M.L. Fisher, "The Impact of the Zimbabwean Liberation Struggle on Botswana: The Case of the Lesoma Ambush, 1978", New Contree, 57, 2009, pp 1-21; R. Dale, "Loosening Connection in Anglophone Southern Africa: Botswana and Rhodesian Regime, 1965-1980", Journal of Contemporary African Studies, 2, 1983, pp 257-258.

8. Morapedi, "The Dilemmas of Liberation", pp 73-90; Makgala and Fisher, "Impact of the Zimbabwean Liberation Struggle”, pp 1-21; Dale, "Loosening Connection”, pp 257-258.

9. D. Wylie, A Little God: The Twilight of Patriarchy in a Southern Africa Chiefdom (Wits University Press, Johannesburg, 1991); and F. Morton, When Rustling Became an Art: Pilane's Kgatla and the Transvaal Frontier, 1820-1902 (David Philip, Claremont, 2009). 
This was so because women had no rights to land in a country that tied the citizenship of its people to their rural roots. ${ }^{10}$ The exclusion of women, despite being the primary food producers, was further affirmed by a highly patriarchal land tenure law, the Tribal Land Act of 1968, which entrusted the allocation of all tribal land to "tribesmen". A subsequent rejoinder of this Act, the Tribal Grazing Land Policy of 1975, was also discriminatory towards women because it gave cattle owners grazing land rights in arable lands in a country where cattle ownership was almost invariably the preserve of men.

In what follows we draw on the Kutlwano magazine, the liberation struggle documents at the Botswana National Archives and Records Services (hereafter BNARS), as well as President Seretse Khama's speeches and the Botswana's Citizenship Act of 1982/1984 to understand how the government of Botswana and the public tried to develop and achieve a rural, peaceful, masculine culture and citizenry against the backdrop of the southern African liberation struggles. Firstly, this article addresses the question of how Botswana, as a landlocked independent state, surrounded by white minority regimes during a tumultuous period of regional liberation wars, attempted to redefine its citizenship model along anti-political masculine lines. Secondly, the article deals with the important question of Botswana's historically rooted patriarchal gender regime and its influence on the country's refashioning of its citizenship model against the backdrop of the influx of refugees from the liberation struggle. Finally, we show how the Citizenship Act of 1982, which was eventually repealed in the 1990s, was designed to diminish the so-called "rebellious" women's citizenship rights by denying their foreign husbands and children citizenship.

\section{"Radical masculinities" and the threat to Botswana's peace}

The perceived "radical masculinities", as we define them, were thought to be embodied by men characterised by anger and resistance to the Botswana patriarchy (borara, the English equivalent of which is male elites) and its hegemonic authority. Moreover, discursively all insurgents, regardless of their gender, were seen by the male elites as expressing a certain type of toxic masculinity that had the potential to disrupt the prevailing conservative patriarchal power in the country. ${ }^{11}$ This masculinity was "radical" because refugees' radical views were perceived to be eroding male elites' entitlements to the maintenance of domestic and political order and peace. It could also weaken patriarchal control of "other" genders, thus threatening to reconfigure historical Tswana understandings of masculine power, as symbolised by the maledominated ruling Botswana Democratic Party (BDP), and disrupt the country's peace and stability. ${ }^{12}$ In 1977, in the words of the then Minister of Public Service and

10. I. Schapera, A Handbook of Tswana Law and Custom (International African Institute, London and Botswana Society, Gaborone, 1994).

11. C.J. Makgala, "The BNF and BDP's 'Fight' for the Attention of the ANC, 1912-2004: A Historical Perspective", Botswana Notes and Records, 38, 2006, pp 120-133.

12. O.D. Selolwane, "Monopoly Politikos: How Botswana's Opposition Parties have Helped Sustain One-Party Dominance”, African Sociological Review, 6, 1, 2002, pp 68-90. 
Information, Daniel Kwelagobe, the opposition Botswana National Front's "love for refugees" put the peace and "security of the country" in serious peril. ${ }^{13}$

In contrast to the supposed "radical masculinities" of the refugees, for Botswana elites it was a self-reliant, rural masculinist citizenry that was integral to building a peaceful country in the midst of liberation struggles and an emerging pattern of internal circular migration. As illustrated in her classic novel, When Rain Clouds Gather (1978), the South Africa-born novelist, Bessie Head, who lived in exile in Serowe, the hometown of Seretse Khama, from the late 1960s to early 1980s, constructed a fictional version of the country's lack of liberation politics as follows:

The colonialists were withdrawing, and the change was not so much a part of the fashionable political ideologies of the new Africa as the outcome of the natural growth of a people ... The tide of African nationalism had swept down the continent and faltered at the northern borders of Botswana. ${ }^{14}$

Citizenship was therefore largely defined against the radical politics of the freedom fighters from southern Africa that sought sanctuary in Botswana. In order to appreciate the gendering of citizenship in postcolonial Botswana, it must accordingly be seen in the regional context through state-refined citizenship by exclusion of the "radical masculinities", which the refugees purportedly presented. In this article, we show, however, that this gendered refashioning of citizenship infringed on the rights of women in the country. This found expression in Unity Dow's (a prominent gender and human rights activist at the time) legal suit against the Botswana government in 1992, in which she argued that the change in citizenship law from birth to patrilineal descent violated women's human rights. Dow's suit shows how a male-dominated government made a conscious policy of excluding women in the development of a rural, peaceful, masculine culture and citizenry at a time of the southern African liberation struggles. ${ }^{15}$

Broadly, this article contributes to a growing interest among Africanist historians to engage with the under-explored early years of African independence, postcolonial development, and nation-building. By analysing rural masculine citizenship in the context of southern African liberation struggles, there is ample ground on which to formulate a comparative analysis with other southern African states that struggled for economic independence from former colonisers and neighbouring white minority regimes and endeavoured to stabilise a citizenry in constant rural-urban flux.

13. Botswana Daily News, 28 January 1977. The Botswana National Front was the main opposition political party in the country.

14. B. Head, When Rain Clouds Gather (Heinemann Educational Books, London, 1978), pp 45,62 .

15. U. Dow (ed.), The Citizenship Case: The Attorney General of the Republic of Botswana vs Unity Dow: Court Documents, Judgments, Cases, and Materials (Lentswe la Lesedi, Gaborone, 1995); U. Dow, "How the Global Informs the Local: The Botswana Citizenship Case”, Health Care Women International, 22, 2001, pp 319-328. 
The social construction of masculinities in southern Africa has become the subject of intense academic inquiry in recent years, with multiple scholars questioning the oft-told narrative of the masculine violations of feminist gender consciousness. ${ }^{16}$ Limited attention has, however, been paid to the construction of rural and revolutionary masculinities and how these intersected and opposed each other. Studies of insurgent masculinities have shown that masculinities and femininities are not always polar opposites and that men are not inherently privileged perpetrators and beneficiaries of gendered power inequalities. ${ }^{17}$ In a southern Africa torn by liberation struggles, insurgent masculinities were complex because they were not constructed on gender-binary consciousness of "man" against "woman". Instead, as exemplified by FRELIMO in Mozambique and the African National Congress in South Africa, they prioritised male-female bonds of comradeship rather than male violence against women. ${ }^{18}$ We begin from this premise that masculinities are not a primordial, timeless and homogenous phenomenon. Rather, they are a fluid, social and historical construct which keeps recalibrating due to changing gender roles and expectations.

\section{Refugees and Botswana's role in the liberation struggle: Imagery and imaginaries}

From the 1970s, with a sharp rise in refugee immigration from surrounding countries, the people of Botswana constructed their citizenship around an idealised rural manhood, which in turn was intended to project and to embody a peaceful, stable nation in a region embroiled in wars of independence predominantly typified by radical and rebellious politics. ${ }^{19}$ Batswana masculinity's rural roots, in which the

16. L. Ouzgane and R. Morrell (eds), African Masculinities: Men in Africa from the Late Nineteenth Century (Palgrave Macmillan, New York (2005); L. Lindsay and S.F. Miescher, Men and Masculinities in Modern Africa (Heinemann, London, 2003); B. Carton, Blood from your Children: The Colonial Origins of Generational Conflict in South Africa (University of Virginia Press, Charlottesville and London, 2000); R. Morrell, "Of Boys and Men: Masculinity and Gender", Southern African Studies, 24, 4, 199), pp 605630; A.F. Isaacman and B. Isaacman, Slavery and Beyond: The Making of Men and Chikunda Ethnic Identities in the Unstable World of South-central Africa, 1750-1920 (Heinemann, Portsmouth, 2004); P. Molosiwa, “Bakgomong: The Babirwa's Transboundary Pastoralist Identity and Social Change in Late 19th Century Botswana", New Contree, 75, July 2016, pp 1-40.

17. L.M.D. Ortega, "Looking beyond Violent Militarized Masculinities: Guerrilla Gender Regimes in Latin America", International Feminist Journal of Politics, 14, 4, 2012, pp 489-507.

18. J. Katto, "Landscapes of Belonging: Female Ex-combatants Remembering the Liberation Struggle in Urban Maputo", Journal of Southern African Studies, 40, 3 (2014), pp 539557; and P. Meth, "Unsettling Insurgency: Reflections on Women's Insurgent Practices in South Africa", Planning Theory and Practice, 11, 2, 2010, pp 241-263; H.T. Ngoshi, "Masculinities in Zimbabwean Autobiographies of Political Struggle: The Case of Edgar Tekere and Fay Chung", Journal of Literary Studies, 29, 3 2013, pp 119-139.

19. S. Khama, "A Statement of Progress and Policy", Kutlwano, May 1970, p 6; Kutlwano, "Editorial: Botswana Surges Forward", April 1972, p 3; and P. van Rensburg, "A New Approach to Rural Development", Botswana Notes and Records, 3, 1971, pp 201-215. 
archetypal man was considered the protector of the "less masculine" and "feminised" groups (in this case women, the youth and poor men) were therefore contrasted with the violent and "heroic" masculinities of the liberation struggle in which insurgents constructed themselves as action heroes. ${ }^{20}$ This behaviour or attitude of the allpowerful male, however, could also reflect the inferiority complex of a Botswana man whose position in society was gradually being undermined by growing gender consciousness among women and youthful males.

The imagery of insurgents exhibiting martial combat characteristics in Botswana between the 1970s and 1980s thus aroused, in the collective imagination of Batswana, suspicions of the country developing social tolerance for violence. From the 1970s on, popular discourse in Botswana centred on citizenship and the threat to the prevailing peace by the "radical masculinities" of refugees. Much of the discursive debates came from an emerging generation of male elites who communicated their feelings primarily through the country's sole magazine and purveyor of local news, Kutlwano. ${ }^{21}$ Through its rural development programmes and rhetoric, government also made a concerted effort to shape rural masculinity and to support a peaceful, stable country in the context of a new culture of localised circular migration (ruralurban-rural migration). This ideal of rural masculinity - through which Kutlwano readers and development workers encouraged Batswana to go "back to the land" and develop a stable, peaceful, prosperous rural "backbone" for the postcolonial nation was the model of citizenship promoted against the alternative model of radical militants, "troublemakers," and "security risks" of the batswakwa or refugees, who were accommodated in Botswana. ${ }^{22}$

David Magang, one of Botswana's entrepreneurial and business icons, who was a member of parliament between the 1970s and 1990s and held several ministerial positions in the ruling Botswana Democratic Party, captured this deeply engrained cultural ethos of peace and anti-radical politics in 2008, when he wrote:

Batswana, are by nature a people of compunction, a people of scruples...the least provocative and the least likely to indulge in extreme forms of villainous acts compared to most nations around them - a streak that endures to this day, and which explains the relative peace and tranquillity that prevail in our midst. ${ }^{23}$

20. E. Unterhalter, "The Work of the Nation: Heroic Masculinity in South African Autobiographical Writing of the Anti-apartheid Struggle", European Journal of Development Research, 12, 2, 2000, pp 157-178.

21. Kutlwano, the English equivalent of which is "being on good terms" or having "mutual understanding", underscores peace and tranquillity in the nation of Botswana.

22. See for example, K.S. Raborokgwe, "We Remain what we are, Modern or No", Kutlwano, October 1974, p 31; G. Moshabi, "Farming an Advantage", Kutlwano, October 1971, p 12; J.M.J. Legwaila, "A Message of Goodwill to the Youth of Botswana", Kutlwano, November 1970, p 19.

23. D. Magang, The Magic of Perseverance: The Autobiography of David Magang (Centre for Advanced Studies of African Societies, Cape Town, 2008), p 21. 
Magang speaks to Botswana's resolve to advance the rights and liberties of individual citizens and those of foreigners through the maintenance of peace. This liberalist ideology is key to understanding how, in the first decade of independence, national policy and discourse centred around shaping a "peaceful country" comprising masculine, rural citizens whose gender mattered more than their regional affiliations. Liberalism became the cause of peace as this tiny nation sought to redefine itself as an exemplar of anti-war and anti-imperialism, particularly through the tenets of "peaceful resolution of conflict" and "peaceful coexistence" that drove its foreign policy of "good neighbourliness" and "non-alignment" to the oppressive white minority regimes surrounding it. In his speeches about his country's pragmatic policy of non-alignment, Seretse Khama professed the doctrine of the natural rights to life and liberty. ${ }^{24}$ By providing a sanctuary for the refugees of the liberation struggle, yet denying them citizenship, the country was adopting the classical liberal belief that governments exist to protect both social and economic civil liberties of people regardless of their origin.

Botswana's unique position at "the heart of southern Africa" influenced its political culture and, in turn, had consequences for a narrowing definition of gendered citizenship. Botswana's official foreign policy of "good neighbourliness" included tenets that speak to peace, such as "peaceful coexistence" and "peaceful resolution of conflict", and can be understood as in part being promoted because it depended on Rhodesian and South African imports and markets. Even so, Seretse Khama was careful to emphasise that Botswana was "non-aligned but far from neutral". ${ }^{25}$ Committed to multiracial democracy in a "beleaguered nation," Khama resented being labelled another Bantustan, hostage, and client state of Rhodesia and South Africa. ${ }^{26}$ He helped draft the Organisation for African Unity (later the African Union, AU) Lusaka Manifesto in 1969, which outlined member states' resolution to achieve liberation through peaceful means. He convened and led, beginning in 1974, the frontline states (the independent African states bordering Rhodesia and South Africa), focusing on Zimbabwean, Namibian, then South African liberation. He also hosted in Gaborone in 1979, the first meeting of the Southern African Development Co-ordination Conference (now Southern African Development Community) to reduce dependence on South Africa.

While Khama's close ties with "African socialists", such as Zambia's Kenneth Kaunda and Tanzania's Julius Nyerere, were based on Pan-Africanism and anti-racism, he disavowed any political ideology. He described his early foreign policy as "dictated

24. S. Khama, From the Frontline: Speeches of Seretse Khama (Hoover Institution Press, Stanford, 1980).

25. Khama, From the Frontline, p 102.

26. Khama, From the Frontline, pp 174, 158, 274. The Bantustans were African homelands created by the apartheid state in South Africa to rid white occupied areas of African residence. For the history of the creation of the Bantustans, see L. Evans, "South Africa's Bantustans and the Dynamics of 'Decolonisation': Reflections on Writing Histories the Homelands", South African Historical Journal, 64, 1, 2012, pp 117-137. 
by reason and common sense rather than emotion or sentiment." 27 He maintained his anti-ideology stance in an address to the Botswana Parliament in 1976 declaring: "People speak of capitalism and socialism but neither of these terms has a great deal of meaning for our people." ${ }^{28}$ Quett Ketumile Masire, Khama's vice president and successor, concurred, rejecting outright any "-ism" label to categorise his politics. Three decades after Khama's 1976 parliamentary speech, Masire, by then president, described his policy as "pragmatic, not ideological", declaring in his memoirs (published in 2006), "we wanted to choose policies that would achieve our desired results, regardless of whether they carried a particular label or 'ism'”. 29

Botswana's peace was actually what attracted exiles such as Bessie Head, a 'mixed-race' South African writer, to Botswana villages. In her literary works she admitted to having a problematic, isolated identity without a "race" or "tribe". ${ }^{30} \mathrm{Head}$ was denied citizenship in Botswana and lived most of her life as a "stateless refugee" and pariah in Serowe (Central District, Botswana). It is our contention that despite being a woman, to Botswana society, Head was a "masculine radical" because of her South African roots and her personal rebelliousness. ${ }^{31}$ The Batswana's imposition of a male identity on Bessie Head reflects their conception of gender identities as flexible. It is still common to hear people labelling a strong, hardworking woman as a man: "Ke monna yoo (she is a man, that one)", as they will say in their praises. Or when a woman is stubborn, aggressive and rebellious, she will be labelled a "man", or "poo (a bull)", which is a derogation of women's expression of power. In fact, Bessie Head concurred with this characterisation of herself as rebellious in most of her writings. She used writing as a method of resistance against racism and patriarchal power and, in a Fanonian sense, her literary works became revolutionary literature. ${ }^{32}$

In When Rain Clouds Gather, Head writes about a fictional black South African exile, Makhaya, who also fled to Botswana in search of peace and his "free country" Utopia, and was constantly under the local and national authorities' surveillance. ${ }^{33}$ The government warned villagers who accommodated him that they should not stick their necks out for a refugee. ${ }^{34}$ Rumours circulated that Makhaya was a "security risk" who intended to smuggle arms over the border and set up a secret military camp in the

27. N. Parsons, W. Henderson and T. Tlou, Seretse Khama, 1921-1980 (Macmillan Botswana, Gaborone, 1995), p 252.

28. K. Moesi "Seretse Khama: The Man who Cheated Misfortune to Lead his Countrymen", Kutlwano, September 1976, p 5.

29. Q.K.J. Masire, Very Brave or Very Foolish? Memoirs of an African Democrat (MacMillan Botswana, Gaborone, 2006), p 147.

30. See for example, B. Head, "Africa”, in M.J. Daymond (ed), The Cardinals, with Meditations and Stories (Heinemann, Oxford, 1995), pp 121 and 125.

31. R. Nixon, "Border Country: Bessie Head's Frontline States," Social Text, 36, 1993, pp 106-137.

32. F. Fanon, The Wretched of the Earth, Trans. C. Farrington (MacGibbon \& Kee, London, 1965), p 179.

33. Head, When Rain Clouds Gather, p 10.

34. Head, When Rain Clouds Gather, p 60. 
bush. ${ }^{35}$ The suspicion visited upon Makhaya and other black South Africans was different from that placed on the white expatriate staff at Swaneng Hill School in Serowe and the Brigades movement that the government of Botswana did not suspect of launching military attacks from inside Botswana, although their unconventional philosophy and leftist politics made Khama uneasy. ${ }^{36}$ Although the expatriates taught and demonstrated self-reliance and ethics in line with the government's conception of rural development, and shaped ideal Batswana rural masculinity, their politics were not in harmony with those of the Botswana government.

There were several reasons for this, and these must be seen in a regional and global southern African context of Botswana as a frontline state against white minority, lethally anti-Communist regimes, at the height of the Cold War. Seretse Khama's government was deeply concerned that even non-militant, anti-apartheid activists such as Patrick van Rensburg, the founder of Swaneng Hill School in Serowe and the Brigades Movement in Botswana, were "security risks" who made Botswana more vulnerable both to South African Defence Force (SADF) and Rhodesian Selous Scout incursions and economic policies that could cripple Botswana if those countries placed embargoes on trade with Botswana. ${ }^{37}$

Violent incursions and acts of sabotage against Botswana did of course occur. The Kazungula ferry, where the Chobe and Zambezi Rivers meet in Botswana, Namibia, Zambia and Zimbabwe, was constantly threatened by Rhodesian incursions. Although Rhodesia did not commit violence in Botswana on the same scale it did against Zimbabwean guerrilla camps in Mozambique, the refugee camp at Dukwi in northeastern Botswana was persistently under threat. Elsewhere, Selous Scouts threw a grenade into a Francistown (in the Northeast District) dance club on 18 May 1977, killing four and wounding many more. Furthermore, fifteen Botswana Defence Force (BDF) soldiers and two youths were killed by Rhodesian Special Air Service troops in the Lesoma Massacre of 27 February 1978. ${ }^{38}$ The most spectacular and gruesome violence the SADF committed in Botswana happened in the late 1980s. Attacks included the 14 June 1985 bombing in Gaborone where fifteen were killed. Subsequent raids occurred against the BDF barracks in Mogoditshane (Gaborone vicinity) in May 1986, and another raid was launched in March 1988 that killed four. ${ }^{39}$ Khama, Botswana, and Batswana in general welcomed and accommodated refugees, but over

35. Head, When Rain Clouds Gather, pp 57, 171.

36. S. Bagnall, Sheila Bagnall's Letters from Botswana, 1966-1974 (Leitlho Publications, Oodi, Botswana, 2001), p 12; W. Henderson, "Brigades, Government, Enthusiasm and Development: A Critical Review of the Martin Report", Botswana Notes and Records, 6, 1974, 179-187; S. Grant, "Swaneng Hill School”, Mmegi, 11 November 2005.

37. Bagnall, Sheila Bagnall's Letters, p 105.

38. Makgala and Fisher, "Impact of the Zimbabwean Liberation Struggle", pp 1-21.

39. For insight into the series of attacks on Botswana, see Mgadla, "A Good Measure of Sacrifice”, pp 33-53; Morapedi, "The Dilemmas of Liberation”, pp 73-90; and R. Dale, "Not Always so Placid a Place: Botswana under Attack", African Affairs, 86, 342, 1987, pp 73-91. 
time a discourse developed about troublemakers and "paper citizens" who stayed in Botswana and allegedly entered into marriages of convenience to take advantage of the host country's resources. As K. Sadiq observes, this discourse of "paper citizens" speaks to how the influx of illegal immigrants who obtained citizenship documentation fraudulently, blurs the definition of citizenship in weak bureaucracies. ${ }^{40}$

\section{Refugees, security risks and youth politics}

In Botswana, the refugees remained outsiders, only given residence because of their political status, and were generally seen as a national security risk. The government was not alone in framing the anti-politics discourse in relation to refugees, regional, and global events. The generation of young Batswana adults who came-of-age with independence and postcolonial economic development, wrestled with the barrage of political, social, and cultural upheavals across the world and attempted to situate themselves and their home country within this global political geography. Many were unable to reconcile Seretse Khama and Quett Masire's anti-militancy approach with their own ethnic-nationalist Tswana anti-political stance against ideology in favour of pragmatism. Having neither inherited an anti-colonial nationalist struggle nor participated in one, many Batswana reacted strongly against the radical student activism that their counterparts practised, even reproaching them. ${ }^{41}$ In 1989, Zaffiro, a South African media specialist, explored the outgoing British colonial politics of "preparing" Batswana for self-rule by finding "suitable Bantu programme material for local broadcasting" from South Africa's Broadcasting Corporation. ${ }^{42}$ The British set the pace and direction of the transition to independence and supported Seretse Khama's moderate and British sympathetic Botswana Democratic Party (BDP) over other "potential Communists" with "alleged ties" to two African liberation movements in South Africa, the Pan-Africanist Congress (PAC) and African National Congress (ANC). Radio was a tool for managing the African political awakening and countering, in particular, Communism and African nationalism. ${ }^{43}$

David Magang explained that his "mildly inflammatory letters" in Kutlwano "did not assume demagogic dimensions, like that of members of other liberation movements such as the ANC of South Africa. Far from taking a militant approach, my colleagues and I opted for a non-combative, less visible strategy." 44 In 1970, while a student in Canada, Joseph Legwaila, who later became Seretse Khama's personal secretary and then Botswana's ambassador to the United Nations, urged Batswana

40. K. Sadiq, Paper Citizens: How Illegal Immigrants Acquire Citizenship in Developing Countries (Oxford University Press, New York, 2009).

41. B. Mokopakgosi, "The University in Botswana and the Liberation Struggle in Southern Africa, 1973-1980", Social Dynamics, 34, 1, 2008, pp 33-45.

42. J.J. Zaffiro, "Twin Births: African Nationalism and Government Information Management in the Bechuanaland Protectorate, 1957-1966", International Journal of African Historical Studies, 22, 1, 1989, pp 51-77.

43. Zaffiro, "Twin Births."

44. Magang, The Magic of Perseverance, p 352. 
youth to be aware of the "demoralizing youth revolutions and counter-revolutions" of the late 1960s. Such radical action, he said, was "not in conformity with the philosophy of those of us who come from peaceful societies where law and order are inherent." Belligerence and "cancerous foreign influence," he wrote, would lead Batswana astray. ${ }^{45}$

The new University of Botswana and Swaziland campus, opened in Gaborone in 1975 following the withdrawal of the National University of Lesotho from the University of Botswana, Lesotho and Swaziland (UBLS), was an important site where refugees and Batswana youth interacted. 46 Khama's government offered accommodation and employment to the handful of radical South African refugee teachers and students, most of whom fled South Africa because of their participation in the South African Student Organisation (SASO) and other student associations. Their affiliations were recorded on the reports which the Botswana police submitted to the refugee advisory council. These reports were used to decide the refugees' asylum status and gauge and ascertain their level of militancy and possible troublemaking.

The refugee students, however, frequently clashed with the university's administration, which monitored them closely, as the government did Swaneng Hill staff. Khama warned refugee students in 1978:

We will not allow you to turn us into what you think we should be. Some of you come from oppressive societies and we are very happy to share our freedom with you in the spirit of African brotherhood, but on condition that you do not abuse your stay here and the freedom you enjoy from it. We will be prepared to ask any one of you who tries to incite our students to disobey established authority in this country to leave us in peace. ${ }^{47}$

Khama therefore viewed their participation in student politics with great unease. By invoking the extended familial bonds of southern Africans (Tswana and Sotho of South Africa and Botswana being either direct kin or culturally similar cousins) through a "spirit of African brotherhood", Khama aimed to pacify antagonists who wanted to continue their activism in Botswana. Some of the foreign students became student council presidents and were often singled out for extra discipline for orchestrating a string of protests that took place on campus in the late 1970s. Khama cautioned students that their stay at the University should not entail "devotion of the study of nihilistic philosophies and destructive revolutionary dogmas which have no relevance whatsoever to prevailing circumstances in your countries". ${ }^{48}$ Members of the so-called "Soweto group", which led the protests and criticised university officials publicly, were deported. ${ }^{49}$ The protests staged by refugees before crossing the border, as well as the riots some of them led in Botswana, made all refugees "radical politicians".

45. J.M.J. Legwaila, "A Message of Goodwill to the Youth of Botswana", Kutlwano, November 1970, p 19.

46. Mokopakgosi, "The University in Botswana and the Liberation Struggle", pp 33-45.

47. Mokopakgosi, "The University in Botswana and the Liberation Struggle", p 42.

48. Mokopakgosi, "The University in Botswana and the Liberation Struggle", p 42.

49. Mokopakgosi, "The University in Botswana and the Liberation Struggle”, p 41. 


\section{Anxieties about refugees and radical politics}

Radical politics threatened stability, peace, and notions of Tswana masculinity that were evidently pragmatic and more conservative, and therefore contradicted Botswana historian, Wazha Marapedi's argument that Batswana migrant men working in the South African mines "stuck tenaciously" to their own culture. ${ }^{50}$ This narrative has a long history in Botswana itself. Botswana's way forward was to maintain, as Seretse Khama urged, the society their "forefathers" had built. ${ }^{51}$ Batswana people have a long history of accommodating refugees since at least as early as the mid-nineteenth century when Batswana merafe (ethnic groups) absorbed bafaladi (refugees) who fled during the difaqane/mfecane in the wake of the Zulu state's consolidation and expansion that shook the subcontinent. ${ }^{52}$ This history was recalled when in 1967-1968 over 3000 Hambukushu and WaYei peasants, displaced respectively in Namibia and southern Angola by the liberation struggle, fled into the most north-western corner of Botswana in the Okavango Delta. Seretse Khama and his English wife, Ruth, visited them and granted them citizenship, celebrating their basket-weaving talents that today are a tourist symbol. ${ }^{53}$ But they were peasants and ostensibly neither political nor troublemakers like the Zimbabwean and South African refugees/exiles. Thus, not all refugees in Botswana were deemed the same. Radical politics was the dividing line.

In 1981, Oliver Tambo, then head of the ANC in exile, thanked President Masire for Botswana's commitment to the liberation struggle. He hoped that ANC exiles were not "troublemakers" like the Zimbabweans who at Dukwi refugee camp "got involved" with local Batswana women, much to the chagrin of local patriarchs. ${ }^{54}$ Botswana policy was "not to alienate but to encourage [refugees] to be involved in activities on the same basis as locals," yet friction escalated between locals and refugees over limited resources. ${ }^{55}$ Regardless, all refugees were detained after crossing the border and heard before special refugee advisory councils in order to determine whether or not they were "genuine". 56

50. W.G. Morapedi, "Acculturation and Botswana Migrant Miners in South Africa, 19301980", Afrika Zamani, 15/16, 2007/2008, pp 45-62.

51. Khama, From the Frontline, pp 322-324.

52. See among others, C. Hamilton, (ed.), The Mfecane Aftermath: Reconstructive Debates in Southern African History (Wits University Press, Johannesburg, 1995); J. Cobbing, "The Mfecane as Alibi: Thoughts on Dithakong and Mbolompo, "The Journal of African History, 29, 3, 1988, pp 487-519.

53. Parsons, Henderson and Tlou, Seretse Khama, p 255.

54. Botswana National Archives and Records Services (hereafter BNARS): Office of the President, Files (OP) 27/1 Liberation Movements, Record of Discussions between H.E. President Dr Q.K.J. Masire and Oliver Tambo, president of the ANC at Gaborone, 27 August 1981.

55. BNARS: Office of the President Files (OP) 27/1 Liberation Movements, 27 August 1981.

56. BNARS: Office of the President Files (OP) 27/1 Liberation Movements, 27 August 1981. 
Refugees were required to go to the nearest police station and fill out a report, be interviewed, and submit a statement explaining why they qualified as political refugees. The police officer reported whether or not the refugee appeared "genuine" based on political affiliations, employment history, connections in Botswana, intentions on entering and leaving Botswana, and other criteria. The point was certainly to prevent Rhodesian and South African spies from penetrating refugee networks and perpetrating acts of sabotage. The Refugee Advisory Council, which drew its membership from senior officers in the police service, district administration and immigration department, then summoned the refugee to appear for questioning upon which official political asylum was either granted or denied. 57 The resentment stemming from the belief that better educated refugees took teaching and other jobs, which the Batswana deserved, fuelled the tension. ${ }^{58}$ Conflicts also arose over housing because many refugees in the towns found accommodation whereas Batswana squatters (controversially known as maipaafela for subverting land policy), a potentially "politically explosive problem",59 had a longer wait despite official decrees that "all Botswana people are free to live where they can make a living". ${ }^{60}$

The tensions surrounding qualification for asylum are illustrated in Bessie Head's novel, When Rain Clouds Gather, which though fictional, draws from her personal experiences while living in Botswana. Here the hostility towards refugees is explored in unsettling detail. The chief of the village in which the novel's main character, Makhaya, made his new home threatened him, saying: "The only man who knows how to do things here is a Botswana man. Most of the trouble here is caused by people from outside and we don't want you. We want you to get out." 61 This moment eloquently captures how central the analysis of Botswana masculinity itself, and in relation to "foreign genders", is to understanding Botswana's position in southern African liberation struggles and its postcolonial development.

The threat of political radicalism was palpable in the townships, especially Lobatse and Francistown, which bordered South Africa and Southern Rhodesia (later Zimbabwe) respectively. With their large population of political refugees and their beer halls becoming the hotbed of political activism, the townships provided a potential

57. BNARS: OP7/16, Selebi-Phikwe Visit of the Hon. F.M.K. Kgabo, Minister of Local Government and Lands, Savingram from Permanent Secretary, Ministry of Local Government and Lands to Permanent Secretary to the President, 18 June 1971. The Refugee Advisory Council, established under section 4 of Botswana's Refugee (Recognition and Control) Act of 1967. See E. Macharia-Mokobi and J. Pfumorodzi, "Adavancing Refugee Protection in Botswana through Improved Refugee Status Determination", African Human Rights Law Journal, 13, 1, 2013, p 172.

58. BNARS: OP 27/78, Refugee Resettlement and Education in Botswana, 12 January 1979 - 4 January 1983.

59. BNARS: OP7/16, Selebi-Phikwe Visit of the Hon. F.M.K. Kgabo, 18 June 1971.

60. BNARS: OP7/16 Selebi-Phikwe Town Council Notes for the Minister of Local Government and Lands for Visit to Selebi-Phikwe, 15 June 1971.

61. Head, When Rain Clouds Gather, p 65. 
refuge for guerrillas from the surrounding white minority-controlled countries. ${ }^{62}$ In When Rain Clouds Gather, Head summarised why the novel's main character, Makhaya, was initially distrusted by Batswana villagers who eventually embraced him: “...foreign men were a fearful unpredictable quantity in an otherwise predictable world." 63 She wrote: "Politicians were supposed to be feared in Botswana", and Makhaya, an educated black South African man, was initially assumed to be one.64

Head's novel in many ways foreshadowed the experiences of Michael Dingake. Born in Bobonong (Bobirwa Sub-district, eastern Botswana), he was educated in Johannesburg where he was radicalised and joined the ANC. Imprisoned for fifteen years on Robben Island, Dingake wrote in his 1987 memoir, My Fight against Apartheid, about the tepid political atmosphere in Botswana in the 1970s and 1980s. He found it "embarrassing" to witness scores across the world organise divestment campaigns and implored Batswana to become "conscientized on the essence of apartheid and how it affects them as individuals and as nations" and mobilise mass solidarity organisations toward the struggle against apartheid. Many ordinary Batswana, he claimed, remained "indifferent and aloof" and sometimes "openly hostile" to the cause of their kin across the border. 65

These attitudes towards refugees, Dingake explained, were most visible by the way Batswana pejoratively called them batswakwa (aliens). In a lengthy critique of this exclusionary discourse on the batswakwa, Dingake argued that Batswana were deeply indebted to "the hospitality and magnanimity of our black brothers across the border" and pointed out that over many decades they depended on them to earn their livelihoods in South Africa. Batswana were obligated to reciprocate both the hospitality and solidarity with South Africans who, he said, never rejected them as "foreigners". He emphasised:

Before political independence we depended very much on our South African brothers when we earned a livelihood in their economy. We were never subjected to subtle discriminations as practised here against "Batswakwa" except by the common enemy - the colour bar/apartheid state. In fact, it was our black brothers who taught us how to survive, how to cheat the pass laws and how to enjoy the limited accommodation with them. We were welcome. We were welcome in the ghettos, in the factories and in the schools. The parents whose children did not find vacancies because of our admission to their limited schools did not curse "Batswakwa". Today we can boast of national leaders who are leading us in the righteous path of independence, who are products of the hospitality and magnanimity of our black brothers across the border.66

62. Parsons, “The Pipeline”, pp 17-32; and Mgadla, “'A Good Measure of Sacrifice”, pp 3353.

63. Head, When Rain Clouds Gather, p 72.

64. Head, When Rain Clouds Gather, p 111.

65. M. Dingake, My Fight against Apartheid (Kliptown Books, Johannesburg, 1987), p 241.

66. Dingake, My Fight against Apartheid, p 241. 
As citizens of an independent black republic, therefore, individual Batswana had a moral duty to receive refugees, extend protections and amenities, such as education and employment, and include batswakwa within the fold of Botswana culture and society.

When he was released from Robben Island in 1981 and returned to Botswana, the country celebrated his safe homecoming and cheered his freedom fighting. However, the majority urged him to retire, or "detach" from his politics in South Africa. Dingake recalled hearing Batswana cry after him, "You've done your bit. Relax! Someone can carry on where you left off!" They wanted him to devote his time to his family and his country instead. While Batswana generally accepted him as one of their own, there was always that unease about his experiences as a radical South African politician. Dingake traced such sentiments to the first, long year of his imprisonment when his father travelled around Botswana from village kgotla to kgotla, seeking assistance and information on his son's condition. Many said to his father, "Your son is a renegade. He should have concerned himself with the political and other developments of his country. Instead, he goes and meddles in other people's affairs" ${ }^{67}$

The distance Batswana placed themselves from the politics of militancy, abrasiveness and troublemaking ("other people's affairs") must be placed in historical context. Batswana abhorred apartheid in no uncertain terms. Indeed, the stories of bloody Boer/Afrikaner raids and cattle theft against Tswana villages and the memories of generations of men and women who worked in the violently racist and dehumanising conditions on the mines and in the homes of white South Africa are deeply ingrained in the collective, national historical consciousness of Botswana. Dingake's "renegade" radicalism helps reveal the tension in Botswana's supposedly anti-political culture of peace and accommodation of refugees, and simultaneous exclusion of a category of radical men.

\section{Anti-radical masculinities legislation: The Citizenship Act}

The 1970s were a pivotal period of shifting gendered terrain that laid the groundwork for transformational political struggles in the late 1980s and 1990s. The political rhetoric around Batswana manhood and anxieties about the refugees reached a climax when the relationship between Tswana masculinity and the state was formally legislated with the passage of the Citizenship Act in 1982, which was amended in 1984. By passing this highly gendered law, the Botswana state legislated a narrowing conception of a masculine citizenry.

This law affirmed the male-oriented, patriarchal authority of Botswana society by excluding "foreign" masculinities and their association with the radical politics of refugees. Officially, however, it shifted universal citizenship by birth to citizenship by descent. For Botswana society, citizenship was always through the father who had to be a citizen, and through the mother only if she were unmarried at the time of the birth

67. Dingake, My Fight Against Apartheid, p 235. 
of her children. Otherwise, children born in Botswana to a Motswana woman married to a non-citizen were "aliens in the land of their birth". 68 This was precisely the case of Unity Dow, whose oldest daughter was a citizen, born out of wedlock, but whose younger daughters were born in Botswana after their Motswana mother and American father had wed. ${ }^{69}$ This case drew support from the Botswana women's movement whose role in the fight for women's citizenship rights is well articulated in recent feminist scholarship on Botswana. ${ }^{70}$ The denial of citizenship rights to these children was legislated for in Section 5 (1), which states: "A person born outside Botswana shall be a citizen of Botswana by descent if, at the time of birth (a) his father was a citizen of Botswana ..."71

The impetus of the law was the so-called "paper citizen" situation, creating an offence alleged against "thankless" refugees who "exploited" Botswana, benefiting from its sanctuary and international aid but who professed no loyalty to their host country. As mentioned above, in his critique of the increasing reliance on official documents for identification in the developing world, Kamal Sadiq advances the theory of paper citizenship wherein fraudulently obtained paperwork often confers documentary citizenship on illegal immigrants. ${ }^{72}$ In Botswana, discourse on "paper citizens" initially framed Zimbabweans who returned home to their liberated country after 1980, many of whom were said to have taken their Batswana wives back to Zimbabwe. Subsequently, the perceived crisis worsened and shifted to South Africans who continued to cross into Botswana. Concomitant with the belief in the early 1980s among Batswana and the African National Congress (ANC) that apartheid would not fall any time soon, Batswana resented the fact that many refugees were simply allowed to live as permanent residents, attend university, take jobs, marry Batswana women, become citizens and thus make Batswana lives vulnerable to South African incursions. ${ }^{73}$

The hostility towards outsiders marrying local women and assuming citizenship in their spouses' countries was a feature of political discourse in early postcolonial southern Africa. This discourse was shaped by the experiences of ruling class elites, such as José Eduardo dos Santos of Angola, Seretse Khama, and Zimbabwe's Robert Mugabe, all of whom had earlier felt unwelcome in the foreign countries where

68. Government of Botswana, Citizenship Act No. 25 of 1982.

69. Dow (ed.), The Citizenship Case.

70. Bauer, "Update on the Women's Movement in Botswana", pp 26-30; G. Bauer, "What is Wrong with a Woman Being Chief? Women Chiefs and Symbolic Substantive Representation in Botswana", Journal of Asian and African Studies, 5, 2, 2016, pp 222237; M.M.M. Bolaane, "Interviews, Court Statements and Speeches: Introduction", in M.M.M. Bolaane, M.S. Lederer, L.S. Molema and C. Rapoo (eds.), Botswana Women Write (University of KwaZulu- Natal Press, Pietermaritzburg, 2019), pp 398-401.

71. Government of Botswana, Citizenship Act No.25 of 1982, Section 5 (1).

72. Sadiq, Paper Citizens.

73. J. van Allen, ''Bad Future Things' and Liberatory Moments: Capitalism, Gender, and the State in Botswana", Radical History Review, 76, 2000, pp 136-168. 
they were married. ${ }^{74}$ Perhaps Seretse Khama's experiences of rejection following his marriage to a white woman earlier in colonial Botswana shaped the Batswana's political views of marriage between foreigners and locals. Khama had married Ruth Williams, a white British woman, in 1948 while studying towards a law degree in England. Opposition to this racially-mixed marriage became a site of convergence of patriarchal interests as the National Party in South Africa (with its anti-miscegenation laws), Botswana's colonial master (the British) and the Bangwato chieftaincy formed an unusual alliance against what they viewed as subversion of their respective powers. ${ }^{75}$ The South African National Party and the British administration were racist masculinities that infantilised all black people while the historically deep-rooted power of the Tswana patriarchy presented a type of masculinity wherein young men could not get married without consent from male elders. The Bangwato royalty could therefore not fathom the idea of an heir to their throne marrying across racial lines and without consent from his male elders.

Khama's marriage to Ruth Williams thus presented a threat to this tripartite of masculinities in a racial context. Eventually, the unique convergence of patriarchal interests led to Seretse's banishment from his country until he was allowed to return in 1956 following his renunciation of his claim to the Bangwato throne. ${ }^{76}$ Patriarchal opposition to interracial marriage was, however, not unique to Botswana. Across imperial Britain, crossing racial sexual boundaries was deplorable and dangerous, with white women who married black men variously described in condescending racial terms as "women of a very low type", 77 degenerate "agents of subversion" of colonial masculinities and in many other gendered and racially-charged epithets. ${ }^{78}$

Political scientist Judith van Allen contends that the Botswana state used a refugee problem to solve the gender problem of the nascent working class of women, matrifocal families, plummeting marriage rates, and a group of women's organisations that emerged in the early 1970s. She writes:

74. A.P. Cheater and R.B. Gaidzanwa, "Citizenship in Neo-patrilineal States: Gender and Mobility in Southern Africa", Journal of Southern African Studies, 22, 2, 1996, p 196.

75. One of the very first pieces of legislation that the National Party passed with its rise to power in 1948 was the Prohibition of Mixed Marriages Act, Act No. 55 of 1949, that forbade marriages across racial lines. See for example, C.K. Jacobson, A.Y. Amoateng, and T.B. Heaton, "Inter-racial Marriages in South Africa", Journal of Comparative Family Studies, 35, 3, 2004, pp 443-458.

76. M. Dutfield, A Marriage of Inconvenience: The Persecution of Ruth and Seretse Khama (U. Hyman, London, 1990).

77. L. Tabili, "Women of a Very Low Type': Crossing Racial Boundaries in Imperial Britain", in L.L. Frader and S.O. Rose (eds), Gender and Class in Modern Europe (Cornell University Press, Ithaca and London, 1996), pp 165-192.

78. T. Keegan, "Gender, Degeneration and Sexual Danger: Imagining Race and Class in South Africa, ca. 1912", Journal of Southern African Studies, 27, 3, Special Issue for Shula Marks 2001, pp 459-477; M. Mushonga, "White Power, White Desire: Miscegenation in Southern Rhodesia, Zimbabwe", African Journal of History and Culture, 5, 1, 2013, pp 1-2. 


\begin{abstract}
Although the government never wavered from its actual policy of welcoming refugees in defiance of Pretoria, its discourse partly shifted to one of restricting refugees, and, not accidentally, of appearing to offer men - primarily as husbands or potential husbands, and secondarily as fathers - reassurance that they had not, after all, "lost control over "their women". That is, the government did not just use the existing gender domination system to "solve" a perceived refugee problem. It used the anxiety over refugees as a tool to attempt to "solve" a perceived gender problem - the fear and anger often expressed by men at all levels of society, from the Attorney General to mine workers to cattle herders, that women were getting out of control, which, to be fair though not sympathetic to the men, was absolutely true. ${ }^{79}$
\end{abstract}

Van Allen's analysis speaks directly to the way the citizenship law was used as a tool to "repackage the traditional patriarchy and patrilineal entitlements" with a view to control, and perhaps challenge, the citizenship rights of women married to foreign men. ${ }^{80}$ We extend van Allen's thesis and argue that the Citizenship Act also solved the specific gender problem of masculinity by excluding, as a category of men, refugees and their associated radical politics and thus legislated for political and cultural ideals of a national Botswana masculinity. As a frontline state, Botswana's "peaceful" rural masculinity (discussed previously) helped redefine citizenship in the light of the forced migrant batswakwa of southern African refugees/exiles and their radical politics. It provided examples against which to define and legislate national, masculine citizenship by excluding foreign men and their foreign ideologies antithetical to the "peaceful" nation of farmers: Botswana.

In his 2008 autobiography, David Magang, who headed the Law Reform Committee that drafted the Act in 1980, wrote that its target was refugees who "hunted for indigenous suitors and entered into marriages of convenience, with hardly any emotional attachment whatsoever". ${ }^{81}$ In Unity Dow's 1992 suit against the government and its subsequent appeal, the Attorney General justified the law because at the time, before South Africa's democratic transition, there was a necessity to "safeguard sovereignty in a large country with a small population and many attractions for the immigrant". ${ }^{2}$ Radical refugees were a "security risk" who made Botswana vulnerable to Rhodesian and South African incursions. They were also "paper citizens", entering into marriages of convenience, to take advantage of generous aid, schools and resources.

The Attorney General, defending the law, further argued that discrimination against women (the basis of Unity Dow's case was that this was unconstitutional) remained applicable in 1992 because "Botswana society is patrilineal" and was needed

79. Van Allen, "Bad Future Things", p 157. For further insight see R. Mookodi, "Women's Life in Botswana”, Canadian Journal of African Studies, 16, 2, 1972, pp 357-358.

80. Cheater and Gaidzanwa, "Citizenship in Neo-patrilineal States", pp 196-197.

81. Magang, The Magic of Perseverance, $\mathrm{p} 371$.

82. Dow (ed.), The Citizenship Case. 
"to preserve the male orientation of Botswana society". ${ }^{83}$ This therefore solved the double gender problem of subordinating Batswana women, who behaved "like men" in their political organisations and whose marriages to foreign men were supposedly subversive of the country's post-colonial neo-patrilineage. The import of this law was therefore to diminish the citizenship rights of mobile women whose marriage unions transcended national lines by denying their children and husbands citizenship. It privileged the rural roots of Botswana patriarchy and masculinity against the radical politics of the region and globally because of the international feminists' interest in the case and solidarity with Unity Dow. ${ }^{84}$ Indeed, in her suit against the government, Unity Dow explained: “...traditionalists charged that I was influenced by foreign ideas and that I was seeking to change their culture." She continued:

There is no justification for the assumption that Batswana women who marry foreigners are more likely than Batswana men marrying foreign women, to be tricked into marriage by persons seeking to marry merely to obtain the benefits of Botswana citizenship. 85

The state used the truism that Botswana has a more "peaceful history" than most to "connect" the problem of women and refugees and to assert control over challenges to its authority and image of a peaceful country under protective, disciplinary, "male oriented" patriarchal authority. ${ }^{86}$

The Citizenship Act reaffirmed Botswana's Tswana-centric cultural and political identities by delegitimising southern Africa's radical ideological alternatives. The masculinity of citizenship was used not only to exclude categories of women (those married to foreign men) but also the category of foreign men. Foreign masculinities antithetical to the peaceful, rural, self-reliant ethic of Botswana masculinity undermined the patriarchal authority and sovereignty of the Botswana state, making it vulnerable to incursions. The law was as much about controlling women as it was about securing Batswana manhood in such precarious times. Botswana citizenship was denied to troublemakers, paper citizens, and batswakwa whose perceived radical political masculinity was a security risk and exploitative of a peaceful country.

The restrictive Citizenship Act, however, had the unintended consequences of catalysing a greater women's political movement, which culminated in international women's and human rights solidarity and Unity Dow's famously successful lawsuit in which the Act was ruled unconstitutional in 1992. With a decade of international African and Western women's feminist and human rights activism for support, Unity

83. Attorney General v. Unity Dow, 1992 BLR 119 (CA), Court of Appeal (Full Bench), Lobatse. Available at http://citizenshiprightsafrica.org/wp-content/uploads/1992/07/AG-vsDow-CA.pdf. Accessed 19 October 2020.

84. Van Allen, "Bad Future Things", p 157.

85. Dow, "How the Global Informs the Local," pp 319-328.

86. A.N. Leslie, Social Movements and Democracy in Africa: The Impact of Women's Struggle for Equal Rights in Botswana (Routledge, New York, 2006), p 58. 
Dow successfully sued the government to overturn the Citizenship Law. Judge Martin Horwitz ruled that the law discriminated against women and was therefore unconstitutional. He concluded, there was no ground for restricting Batswana women from marrying foreign men because "No evidence of any great national concern, such as security, and such like has been placed before me", to justify the Citizenship Act. ${ }^{87}$ Rather, he argued, it affected national security adversely if it forced Batswana families either to split up or leave the country. "The time that women were treated as chattels or were there to obey the whims and wishes of males is long past and it would be offensive to modern thinking" if Batswana women were denied the freedom to choose to marry a non-citizen or not. ${ }^{88}$ The Act undermined the sanctity of marriage because a woman would be compelled to leave Botswana with her family should her husband and non-citizen children be expelled. ${ }^{89}$ Judge Horwitz therefore appealed to the long legacy of the disintegration of families and society caused by emigration (labour migration) in Botswana's history, writing: "The general intention of laws should be to uphold the morality and sanctity of marriage and family life." This Act had "the opposite effect of encouraging illegitimacy, the splitting of families and putting up obstacles in the way of building a family unit". 90

\section{Conclusion}

The intersection of citizenship rights and masculinities is still under-studied in Botswana to date. Even in gender studies, scholarship has focused primarily on the hegemonic power of masculinity and its influence on sexual relations wherein men are presented as inherent perpetrators of sexual violence against women. ${ }^{91}$ This grand narrative is understandable given that much of this scholarship emerged at a time when the country was struggling to cope with an epidemic of gender-based violence in tandem with staggering rates of HIV/AIDS infections. Nonetheless, bringing genderbased violence under the microscope broadens our understanding of the differentiated social contexts in which masculinities are constructed.

This article has analysed how a rural masculine citizenry was "developed" to make a peaceful country in the midst of radical politics, refugees, and southern African liberation struggles. Between independence in 1966 and the early 1990s, Botswana

87. High Court of Botswana, "In the High Court of Botswana Held at Lobatse", Human Rights Quarterly, 13, 4, 1991, pp 614-626.

88. High Court of Botswana, "In the High Court of Botswana", p 623.

89. S. Coldham, "In the High Court of Botswana: Unity Dow vs Attorney-General (Botswana)", Journal of African Law, 36, 1, 1992, pp 91-92.

90. High Court of Botswana, "In the High Court of Botswana”, pp 622.

91. See among others, T. Modie-Moroka, "Masculinities, Gender-based Violence, HIV and AIDS in Botswana", Pula: Botswana Journal of African Studies, 30, 2, 2016, pp 284-297; B.N. Ngwenya, "Gender, Dress and Self-Empowerment: Women and Burial Societies in Botswana", African Sociological Review, 6, 2, 2002, pp 1-27; O.P.K. Nthomang and D. Ntseane, "Alcohol Abuse, Gender-based Violence and HIV/AIDS in Botswana: Establishing the Link Based on Empirical Evidence", Journal of Social Aspects of HIV/AIDS, 2, 1, 2005, pp 188-202. 
drew from its cultural repertoire wherein the rural work ethic shaped gender relations to refashion its citizenship against foreign radical masculinities. The passage of the Citizenship Act in 1982 affirmed the male-oriented, patriarchal authority of Botswana society by excluding foreign masculinities and their association with the radical politics of the liberation struggle. This Act thus solved the specific gender problem of masculinity by excluding, as a category of men, refugees and their associated radical politics. Official rhetoric and public discourse warned against giving citizenship to the refugees of the liberation struggle whose radicalism would threaten the "peace and tranquillity" that reigned in a country surrounded by hostile white minority regimes. While refining citizenship against the radical masculinities of foreigners had the intended objective of buttressing patriarchal control and "safeguarding" the country's peace, it also produced unintended consequences. In particular, it precipitated the rise of a strong women's rights movement in the country as women, buoyed by Dow's victory against the Citizenship Law, launched an aggressive challenge against the hegemonic power of masculinities.

\section{REFERENCES}

Arnold, G., The A to Z of the Non-Aligned Movement and Third World (Scarecrow Press, Plymouth, 2006).

Attorney General v. Unity Dow 1992 BLR 119 (CA), Court of Appeal (Full Bench), Lobatse. Available at http://citizenshiprightsafrica.org/wp-content/uploads/1992/07/AGvs-Dow-CA.pdf (accessed 19 October 2020).

Bagnall, S., Sheila Bagnall's Letters from Botswana, 1966-1974 (Leitlho Publications, Oodi, 2001).

Bauer, G., “Update on the Women's Movement in Botswana: Have Women Stopped Talking?", African Studies Review, 54, 2 (2011).

Bauer, G., "What is Wrong with a Woman Being Chief? Women Chiefs and Symbolic Substantive Representation in Botswana", Journal of Asian and African Studies, 5, 2 (2016).

Bolaane, M.M.M., "Interviews, Court Statements and Speeches: Introduction", in Bolaane, M.M.M., Lederer, M.S., Molema, L.S. and C. Rapoo, C. (eds), Botswana Women Write (University of KwaZulu-Natal Press, Pietermaritzburg, 2019).

Botswana Daily News, 28 January 1977.

Carton, B., Blood from your Children: The Colonial Origins of Generational Conflict in South Africa (University of Virginia Press, Charlottesville and London, 2000).

Cheater, A.P. and Gaidzanwa, R.B., "Citizenship in Neo-patrilineal States: Gender and Mobility in Southern Africa”, Journal of Southern African Studies, 22, 2 (1996).

Cobbing, J., "The Mfecane as Alibi: Thoughts on Dithakong and Mbolompo", Journal of African History, 29, 3 (1988).

Coldham, S., "Unity Dow versus Attorney-General (Botswana)", Journal of African Law, 36, 1 (1992).

Dale, R., "Loosening Connection in Anglophone Southern Africa: Botswana and Rhodesian Regime, 1965-1980", Journal of Contemporary African Studies, 2 (1983). 
Dale, R., "Not Always so Placid a Place: Botswana under Attack", African Affairs, 86, 342 (1987).

Dow, U. (ed.), The Citizenship Case: The Attorney General of the Republic of Botswana versus Unity Dow: Court Documents, Judgments, Cases, and Materials (Lentswe la Lesedi, Gaborone, 1995).

Dow, U., "How the Global Informs the Local: The Botswana Citizenship Case," Health Care Women International, 22 (2001)

Dutfield, M., A Marriage of Inconvenience: The Persecution of Ruth and Seretse Khama (U. Hyman, London, 1990).

Evans, L., "South Africa's Bantustans and the Dynamics of 'Decolonisation': Reflections on Writing Histories the Homelands", South African Historical Journal, 64, 1 (2012).

Evans, M., "The Frontline-States, South Africa and Southern African Security: Military Prospects and Perspectives", Zambezia, 12 (1984/5).

Fanon, F., The Wretched of the Earth, Trans. C. Farrington (MacGibbon \& Kee, London, 1965).

Government of Botswana, Citizenship Act No. 25 of 1982, Section 5 (1).

Hamilton, C., (ed.), The Mfecane Aftermath: Reconstructive Debates in Southern African History (Wits University Press, Johannesburg, 1995).

Head, B., "Africa”, in Daymond, M.J. (ed), The Cardinals, with Meditations and Stories (Heinemann, Oxford, 1995).

Head, B., When Rain Clouds Gather (Heinemann Educational Books, London, 1978).

Henderson, W., "Brigades, Government, Enthusiasm and Development: A Critical Review of the Martin Report", Botswana Notes and Records, 6 (1974).

High Court of Botswana, "In the High Court of Botswana Held at Lobatse", Human Rights Quarterly, 13, 4 (1991).

https://issafrica.s3.amazonaws.com/site/uploads/SAReport Issue4.pdf (accessed 19 April 2021).

Isaacman, A.F. and Isaacman, B., Slavery and Beyond: The Making of Men and Chikunda Ethnic Identities in the Unstable World of South-central Africa, 1750-1920 (Heinemann, Portsmouth, 2004).

Katto, J., "Landscapes of Belonging: Female Ex-combatants Remembering the Liberation Struggle in Urban Maputo", Journal of Southern African Studies, 40, 3 (2014).

Keegan, T., "Gender, Degeneration and Sexual Danger: Imagining Race and Class in South Africa, ca. 1912", Journal of Southern African Studies, 27, 3, Special Issue for Shula Marks (2001).

Keitseng, F., Comrade Fish: Memories of a Motswana in the ANC Underground (Pula Press, Gaborone, 1999).

Khama, S., From the Frontline: Speeches of Seretse Khama (Hoover Institution Press, Stanford, 1980).

Kutlwano, May 1970 to 1976.

Leslie, A.N., Social Movements and Democracy in Africa: The Impact of Women's Struggle for Equal Rights in Botswana (Routledge, New York, 2006).

Lindsay, L., and Miescher, S.F., Men and Masculinities in Modern Africa (Heinemann, London, 2003). 
Magang, D., The Magic of Perseverance: The Autobiography of David Magang (Centre for Advanced Studies of African Societies, Cape Town, 2008).

Makgala, C.J. and Fisher, M.L., "The Impact of Zimbabwean Liberation Struggle on Botswana: The Case of the Lesoma Ambush, 1978", New Contree, 57 (2009).

Makgala, C.J., "The BNF and BDP's 'Fight' for the Attention of the ANC, 1912-2004: A Historical Perspective, Botswana Notes and Records, 38 (2006).

Masire, Q.K.J., Very Brave or Very Foolish? Memoirs of an African Democrat (MacMillan, Gaborone, 2006).

Meth, P., “Unsettling Insurgency: Reflections on Women's Insurgent Practices in South Africa", Planning Theory \& Practice, 11, 2 (2010).

Mgadla, P.T., "'A Good Measure of Sacrifice': Botswana and the Liberation Struggles in Southern Africa (1965-1985)", Social Dynamics, 34, 1 (2008).

Mmegi, 11 November 2005.

Modie-Moroka, T., "Masculinities, Gender-based Violence, HIV and AIDS in Botswana", Pula: Botswana Journal of African Studies, 30, 2 (2016).

Mokopakgosi, B., "The University in Botswana and the Liberation Struggle in Southern Africa, 1973-1980", Social Dynamics, 34, 1 (2008).

Molosiwa, P., "Bakgomong: The Babirwa's Transboundary Pastoralist Identity and Social Change in Late 19th Century Botswana", New Contree, 75 (July 2016).

Mookodi, R., “Women's Life in Botswana”, Canadian Journal of African Studies, 16, 2 (1972).

Morapedi, W.G., "Acculturation and Botswana Migrant Miners in South Africa, 19301980", Afrika Zamani, 15/16 (2007-2008).

Morapedi, W.G., "The Dilemmas of Liberation in Southern Africa: The Case of Zimbabwean Liberation Movements and Botswana, 1960-1979", Journal of Southern African Studies, 38, 1 (2012).

Morrell, R., "Of Boys and Men: Masculinity and Gender", Southern African Studies, 24, 4 (1998).

Morton, F., When Rustling Became an Art: Pilane's Kgatla and the Transvaal Frontier, 1820-1902 (David Philip, Claremont, 2009).

Mushonga, M., "White Power, White Desire: Miscegenation in Southern Rhodesia, Zimbabwe", African Journal of History and Culture, 5, 1 (2013).

Ngoshi, H.T., "Masculinities in Zimbabwean Autobiographies of Political Struggle: The Case of Edgar Tekere and Fay Chung", Journal of Literary Studies, 29, 3 (2013).

Ngwenya, B.N., "Gender, Dress and Self-Empowerment: Women and Burial Societies in Botswana", African Sociological Review, 6, 2 (2002).

Nhlekisana, R.O.B., "A Reflection on Setswana Proverbs in Botswana's National Psyche and Nationhood", Botswana Notes and Records, 48. Special Issue on Humanities at UB and Botswana's 50 Years of Independence (2016).

Niemann, M., "Diamonds are a State's Best Friend: Botswana's Foreign Policy in Southern Africa", Africa Today, 40, 1 (1993).

Nixon, R., “Border Country: Bessie Head's Frontline States," Social Text, 36 (1993),

Nthomang, O.P.K. and Ntseane, D., "Alcohol Abuse, Gender-based Violence and HIV/AIDS in Botswana: Establishing the Link Based on Empirical Evidence", Journal of Social Aspects of HIV/AIDS, 2, 1 (2005). 
Ntseane D. and Mupedziswa, R., "Fifty Years of Democracy: Botswana's Experience in Caring for Refugees and Displaced Persons", International Journal of Development and Sustainability, 7, 4 (2018).

O'Laughlin, B., "Missing Men? The Debate over Rural Poverty and Women-Headed Households in Southern Africa", Journal of Peasant Studies, 25, 1 (1998).

Ortega, L.M.D., "Looking beyond Violent Militarized Masculinities: Guerrilla Gender Regimes in Latin America", International Feminist Journal of Politics, 14, 4 (2012).

Ouzgane L. and R. Morrell, R., (eds), African Masculinities: Men in Africa from the Late Nineteenth Century (Palgrave Macmillan, New York, 2005).

Parsons, N., “The Pipeline: Botswana's Reception of Refugees, 1956-1968", Social Dynamics 34, 1 (2008).

Parsons, N., Henderson, W. and Tlou, T., Seretse Khama, 1921-1980 (Macmillan Botswana, Gaborone, 1995).

Sadiq, K., Paper Citizens: How Illegal Immigrants Acquire Citizenship in Developing Countries (Oxford University Press, New York, 2009).

Saunders, C., "Botswana and the Liberation of Southern Africa", Social Dynamics, 34, 1 (2008).

Schapera, I., A Handbook of Tswana Law and Custom (International African Institute, London and Botswana Society, Gaborone, 1994).

Selolwane, O.D., “Monopoly Politikos: How Botswana's Opposition Parties have Helped Sustain One-Party Dominance", African Sociological Review, 6, 1 (2002).

Tabili, L., "'Women of a very Low Type': Crossing Racial Boundaries in Imperial Britain”, in Frader, L.L. and Rose, S.O. (eds), Gender and Class in Modern Europe (Cornell University Press, Ithaca and London, 1996).

Unterhalter, E., "The Work of the Nation: Heroic Masculinity in South African Autobiographical Writing of the Anti-apartheid Struggle", European Journal of Development Research, 12, 2 (2000).

Van Allen, J., "'Bad Future Things' and Liberatory Moments: Capitalism, Gender, and the State in Botswana", Radical History Review, 76 (2000).

Van Rensburg, P., "A New Approach to Rural Development", Botswana Notes and Records 3 (1971).

Wylie, D., A little God: The Twilight of Patriarchy in a Southern Africa Chiefdom (Wits University Press, Johannesburg, 1991).

Zaffiro, J.J., "Twin Births: African Nationalism and Government Information Management in the Bechuanaland Protectorate, 1957-1966", International Journal of African Historical Studies, 22, 1 (1989). 